\title{
The impact of arbuscular mycorrhizal fungi and temperature on root system development
}

\author{
PJ Forbes, CH Ellison, JE Hooker \\ Soil Biology Unit, Land Resources Department, SAC, Doig Scott Building, Craibstone Estate, Aberdeen AB21 9TQ, UK
}

(Received 30 July 1996; accepted 23 September 1996)

\begin{abstract}
Summary - The impact of arbuscular mycorrhizal fungi on the development and architecture of plant root systems is now widely recognized. However, interactions with environmental parameters, important in natural and agricultural systems, have not been identified. This study utilized microcosms to determine the effects of differences in temperature $\left(15,21\right.$ and $\left.27^{\circ} \mathrm{C}\right)$ on changes to the root system of Plantago lanceolata induced by the arbuscular mycorrhizal fungus Glomus mosseae. In contrast to studies with other plant species, colonization by the arbuscular mycorrhizal fungus reduced root branching and interactions with temperature were identified. There was no correlation between arbuscular mycorrhizal fungi effects on branching and colonization of the root system. Possible implications of the data are discussed.
\end{abstract}

arbuscular mycorrhizal fungi / root architecture / temperature / Plantago lanceolata / Glomus mosseae

Résumé - Impact des champignons mycorhizogènes arbusculaires et de la température sur le développement du système racinaire. L'impact des champignons mycorhizogènes arbusculaires sur le développement et l'architecture des systèmes racinaires est maintenant largement reconnu. Cependant les interactions avec des paramètres environnementaux, importants dans des systèmes naturels et agricoles, n'ont pas encore été identifiées. Cette étude utilise les microcosmes pour déterminer les effets des différentes températures $\left(15,21,27^{\circ} \mathrm{C}\right)$ sur le changement du système racinaire de Plantago lanceolata induits par le champignon mycorhizogène arbusculaire Glomus mosseae. À l'opposé des plantes appartenant à d'autres espèces, la colonisation par le champignon mycorhizogène réduit la ramification des racines. Des interactions avec la température ont été identifiées mais on n'a pas observé de corrélations entre effet du champignon mycorhizogène et colonisation des racines. Des implications possibles de ces résultats sont discutées.

champignon mycorhizogène arbusculaire / architecture racinaire / température / Plantago lanceolata / Glomus mosseae

\footnotetext{
${ }^{*}$ Correspondence and reprints
} 


\section{INTRODUCTION}

Micropropagation is a useful biotechnological tool now frequently applied to plant production. It offers the capacity to rapidly increase numbers of particular genotypes and thus expediate breeding programmes. Other benefits include the multiplication of disease-free, uniform plants. Micropropagated plants are, however, more susceptible to environmental stresses in the weaning stage of growth due to poor root, shoot and cuticular development (Hooker et al, 1994), and this can lead to losses and thus to increased production costs. However, inoculation of micropropagated plants with arbuscular mycorrhizal fungi (AMF) post vitro has been shown to be beneficial for many species, eg, pineapple (Guillemin et al, 1992), avocado (Azcón-Aguilar et al, 1992) and cherry rootstocks (Berta et al, 1995). Benefits can be substantial with increases in growth, a reduction in weaning time and protection against pathogens reported.

An important consequence of colonization by AMF is alteration to root system architecture, with increased branching reported for many species (see review by Hooker and Atkinson, 1996), and it can be assumed to be one of the major mechanisms through which benefits to plants are realized. However, it is not known whether the scale or nature of AMF induced changes to root system architecture may be modified by interactions with the environment. Clearly, if AMF are to be used as a tool to modify plant root systems in either micropropagated or traditionally propagated plants, then a consistent response to inoculation is needed. It is thus important to understand how environmental factors will interact.

This paper describes how temperature interacts with AMF induced modifications to root system architecture in Plantago lanceolata. The study utilized microcosms which allowed a homogeneous distribution of nutrients around the root system. Furthermore, because nutrients were provided continuously, nutritional factors were not responsible for observed responses.

\section{MATERIALS AND METHODS}

Glass microcosms were filled with silica gravel which had previously been washed and graded using a $2 \mathrm{~mm}$ sieve and autoclaved $\left(121^{\circ} \mathrm{C}\right.$ for $60 \mathrm{~min}$, twice) before oven-drying at $150^{\circ} \mathrm{C}$. Thirty microcosms were utilized and AMF inoculum (Glomus mosseae, BEG12) was added to 15 of them by mixing root pieces $(1 \mathrm{~cm})$ of colonized roots with the gravel before adding it to the microcosm. Non-colonized root pieces were added to controls.

Seeds of $P$ lanceolata were surface sterilized in $10 \%$ sodium hypochlorite for $10 \mathrm{~min}$, then rinsed in sterile deionized water before planting into the centre of each microcosm (three seeds per microcosm). Each microcosm was covered with a sun bag ${ }^{\mathrm{TM}}$ (Sigma), and ten microcosms (five inoculated and five uninoculated) placed into each of three Conviron ${ }^{\mathrm{TM}}$ growth cabinets, allowing the microcosms to be maintained at either 15,21 or $27{ }^{\circ} \mathrm{C}$. After germination two seeds were removed to leave just one plant per microcosm. The microcosms were continuously supplied with $1 / 4$ strength Long Ashton nutrient solution using an Ismatec ${ }^{\top M}$ peristaltic pump which delivered at a rate of $70 \mathrm{~mL} /$ day to the plants via four entry tubes equally spaced along the top of the microcosm (fig 1). While in the growth cabinets, the glass of the microcosm was covered with thick black polythene, secured with Velcro $^{\mathrm{TM}}$ to protect the root system from the inhibitory effects of light. A $16 \mathrm{~h}$ day and $75 \%$ humidity were maintained in each growth cabinet.

The plants were grown for 20 weeks before harvesting. The architecture of five secondary roots and associated higher order roots were determined by dissection and measurement using a Quantimet 600 image analysis system (Leica ${ }^{\circledR}$ ).

Samples of the remaining roots were assessed for arbuscular mycorrhizal colonization by staining using a procedure adapted from Koske and Gemma (1989). The extent of arbuscular mycorrhizal colonization was measured using a grid intersect method adapted from Giovannetti and Mosse (1980).

Root and shoot fresh weights were measured and shoots were dried to constant weight at $80^{\circ} \mathrm{C}$. Mortality of roots was also determined but the data are not reported here.

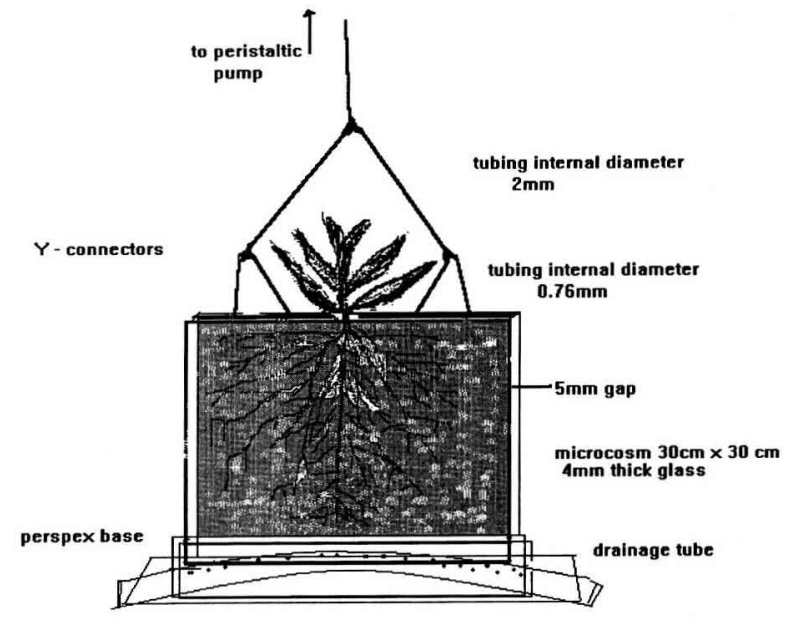

Fig 1. Diagram showing microcosm in which Plantago lanceolata was grown. This microcosm was designed to enable maximum visualization of the root system and a definable nutrient supply to the plant. 


\section{RESULTS}

The growth of Plantago was clearly altered by both temperature and inoculation with the AMF $G$ mosseae (fig 2). Growth was highest at $15^{\circ} \mathrm{C}$ and lowest at $27{ }^{\circ} \mathrm{C}$. At $15{ }^{\circ} \mathrm{C}$, a reduction in growth of approximately $30 \%$ occurred as a result of inoculation. This negative effect of inoculation on growth did not occur at other temperatures where no significant effects on growth were observed.

Colonization by AMF was observed in the roots of all inoculated plants with both vesicles and arbuscules clearly discernable. The highest level of colonization occurred in the roots of plants grown at $15{ }^{\circ} \mathrm{C}(52 \%)$ and the lowest $(36 \%)$ when plants were grown at $27^{\circ} \mathrm{C}$ (fig 3 ). Differences were also evident in the extent to which different root orders were colonized (fig 4) with higher order roots generally being more colonized.

Effects of temperature on the branching of roots were evident (table I) but effects of AMF were limited, with a reduction of branching of approximately $15 \%$ measured at $21^{\circ} \mathrm{C}$.

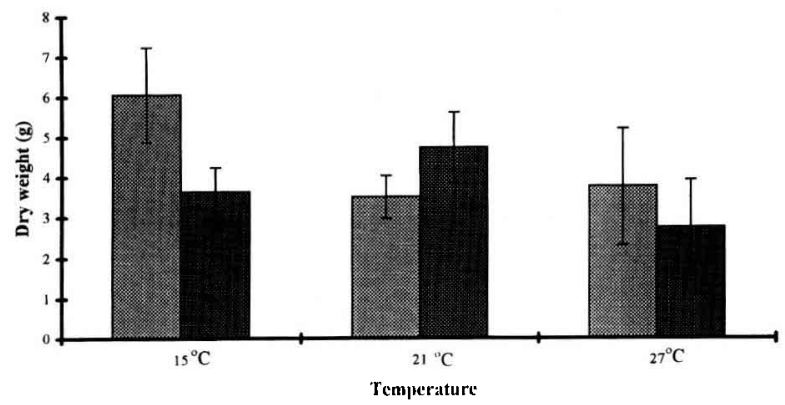

Fig 2. Dry weight of Glomus mosseae colonized ( $($ ) and non-colonized ( $⿴ 囗 0)$ Plantago lanceolata grown (shoots and roots) at three temperatures $\left(15,21\right.$ and $\left.27^{\circ} \mathrm{C}\right)$.

\section{DISCUSSION}

The use of continuous flow microcosms in this study permitted the direct determination of the effects of temperature and AMF colonization on root branching in $P$ lanceolata root systems. The differences in the growth of plants (fig 2) at the different temperatures is not surprising and to be expected. That more growth of $P$ lanceolata occurred at $15{ }^{\circ} \mathrm{C}$ is also reasonable given the distribution of the plant throughout temperate ecosystems. However, what was not expected was the negative effects on growth of colonization by AMF. This is in contrast to the great

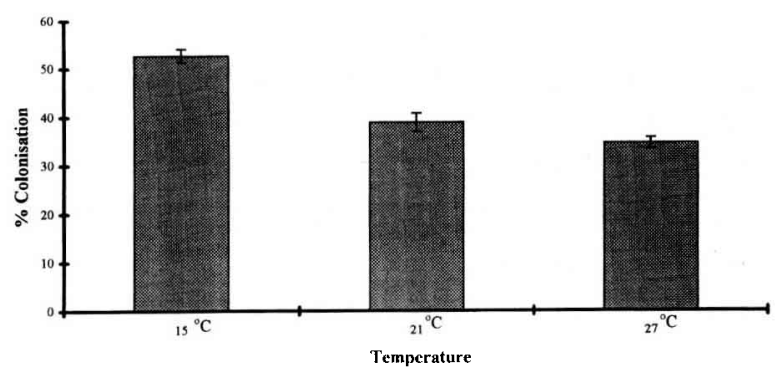

Fig 3. Colonization of Plantago lanceolata roots by Glomus mosseae at 15,21 and $27^{\circ} \mathrm{C}$.

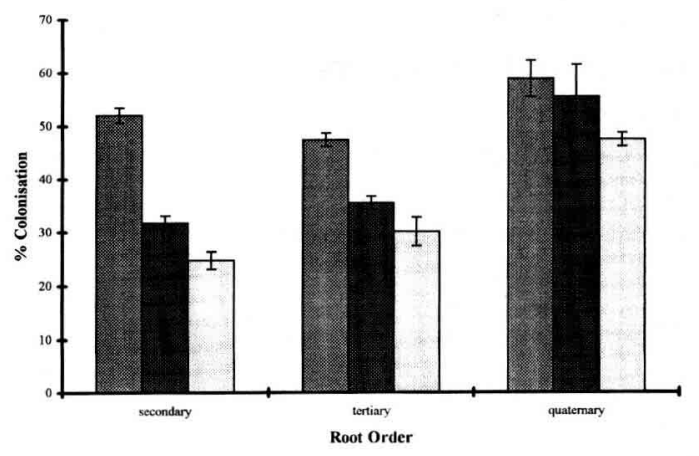

Fig 4. Colonization of Plantago lanceolata roots (different orders) by Glomus mosseae at 15,21 and $27^{\circ} \mathrm{C}$.

Table I. Branching (roots $\mathrm{m}^{-1}$ ) of Plantago lanceolata roots inoculated or uninoculated with the arbuscular mycorrhizal fungus (AMF) Glomus mosseae.

Primary (SE)

Secondary (SE)

Tertiary (SE)

$\begin{array}{llllllll}\text { Control } & 15^{\circ} \mathrm{C} & 180.68 & (29) & 262.06 & (16) & 11.14 & (2) \\ \text { AMF } & 15^{\circ} \mathrm{C} & 127.54 & (38) & 227.90 & (19) & 11.40 & (3) \\ \text { Control } & 21^{\circ} \mathrm{C} & 150.57 & (18) & 422.43 & (45) & 27.09 & (8) \\ \text { AMF } & 21^{\circ} \mathrm{C} & 141.79 & (42) & 342.72 & (29) & 25.57 & (4) \\ \text { Control } & 27^{\circ} \mathrm{C} & 133.33 & (14) & 277.79 & (25) & 22.88 & (2) \\ \text { AMF } & 27^{\circ} \mathrm{C} & 165.85 & (24) & 289.20 & (18) & 22.64 & (4)\end{array}$


majority of the literature on AMF and is at least initially surprising, but can be explained by the system in which the plants were grown. In these systems the continuous flow of nutrients past the root system makes the symbiosis redundant from a nutrient standpoint. However, the costs of supporting the symbiosis remain and it is thus not unreasonable for a negative effect on growth to occur, particularly at $15^{\circ} \mathrm{C}$ where photosynthesis would be relatively low.

Effects of AMF on root branching and thus architecture were, in this study, not large (table I). Moreover, although almost all reports to date of AMF effects on root branching identify increases (Hooker and Atkinson, 1996; Schellenbaum et al, 1991), in this study a reduction in branching was evident in AMF colonized plant roots. The reasons for this are not clear but the data suggests two possibilities. First, it is possible that in this particular species of plant, $P$ lanceolata, colonization by AMF can result in a reduction in root branching. Second, it is possible that changes normally reported are in fact net changes, resulting from a balance between the AMF directly causing a reduction, while increasing branching through an increased phosphorus supply. This clearly deserves further investigation. However, what does seem clear from these data is that there is no direct relationship between AMF colonization and branching. Most alteration was evident at $21{ }^{\circ} \mathrm{C}$ where colonization was only approximately $70 \%$ of that at the lower temperature.

In conclusion, the data clearly go at least some way to providing an understanding of how AMF interact with plant root systems. They also demonstrate the importance of AMF interactions with temperature and suggest that AMF plant root interactions will be modified by temperature in natural and managed ecosystems. Moreover, they also highlight the importance of understanding the effects of temperature on these interactions if AMF are to be effectively applied as a biotechnological tool to modify plant root systems.

\section{ACKNOWLEDGMENTS}

This research was supported by the Commission of the European Community (contract no EV5V-CT-930288). SAC receives financial support from the Scottish Office Agriculture Environment and Fisheries Department (SOAEFD).

\section{REFERENCES}

Azcón-Aguilar C, Barcelo A, Vidal MT, de le Vina G (1992) Further studies on the influence of mycorrhizae on growth and development of micropropagated avocado plants. agronomie 12, 837-840

Berta G, Trotta A, Fusconi A, Hooker JE, Munro M, Atkinson D, Giovannetti M, Morini S, Fortuna P, Tisserant B, Gianinazzi-Pearson V, Gianinazzi S (1995) Arbuscular mycorrhizal induced changes to plant growth and root system morphology in Prunus cerasifera. Tree Physiol 15, 281-293

Giovannetti M, Mosse B (1980) An evaluation of techniques for measuring vesicular arbuscular mycorrhizal infection in roots. New Phytol 84, 489-500

Guillemin JP, Gianinazzi S, Trouvelot A (1992) Screening of arbuscular endomycorrhizal fungi for establishment of micropropagated pineapple plants. agronomie 12, 831-836

Hooker JE, Atkinson D (1992) Application of computeraided image analysis to studies of arbuscular endomycorrhizal fungi effects on plant root system morphology and dynamics. agronomie 12, 821-824

Hooker JE, Atkinson D (1996) Arbuscular mycorrhizal fungi induced alteration to tree root architecture and longevity. Z Pflanz Bodenk 159, 229-234

Hooker JE, Gianinazzi S, Vestberg M, Barea JM, Atkinson D (1994) The application of arbuscular mycorrhizal fungi to micropropagation systems: an opportunity to reduce chemical inputs. Agric Sci Finn 3, 227-232

Koske RE, Gemma JN (1989) A modified procedure for staining roots to detect VA mycorrhizas. Mycol Res 92, 486-505

Schellenbaum L, Berta G, Ravolanirina F, Tisserant B, Gianinazzi S, Fitter AH (1991) Influence of endomycorrhizal infection on root morphology in a micropropagated woody plant species (Vitis vinifera $\mathrm{L}$ ). Ann Bot 68, 135-141 